\section{Densely Planted Okra for Destructive Harvest: II. Effects on Plant Architecture}

\author{
Yaying Wu ${ }^{1}$, Brian A. Kahn², and Niels O. Maness ${ }^{3}$ \\ Department of Horticulture and Landscape Architecture, Oklahoma State \\ University, Stillwater, OK 74078-6027
}

John B. Solie ${ }^{3}$ and Richard W. Whitney ${ }^{4}$

Department of Biosystems and Agricultural Engineering, Oklahoma State University, Stillwater, OK 74078

\author{
Kenneth E. Conway ${ }^{3}$ \\ Department of Entomology and Plant Pathology, Oklahoma State University, \\ Stillwater, OK 74078
}

Additional index words. Abelmoschus esculentus, mechanical harvest, plant morphology, plant population, spacing

\begin{abstract}
Research was conducted to develop a cultural system that would permit a destructive mechanical okra [Abelmoschus esculentus (L.) Moench] harvest. This paper reports on studies to determine the responses of okra plant architecture to various highly dense (HD) plant populations, and to consider the implications of those responses for destructive mechanical harvest. Growing okra in plant arrangements more densely planted than the control (which was spaced at $90 \times 23 \mathrm{~cm}$ ) did not affect overall plant heights. The position of the first bloom or fruit attachment and of the first marketable fruit attachment tended to become higher on the stem as plant population density increased, especially when comparing plants from the $15 \times 15 \mathrm{~cm}$ spacing to control plants. The number of marketable fruit per plant was usually unaffected by plant population. Branch number and defruited dry weight per plant decreased as plant population density increased. Plant architecture did not affect the ability of an experimental mechanical harvester to recover marketable fruit from three different okra cultivars grown in a HD arrangement. The lack of concentrated marketable fruit set, rather than plant architecture, was the main limiting factor to the success of densely planted okra for destructive harvest.
\end{abstract}

Plant population can significantly influence plant architecture. There are several reports of okra plant morphology being affected by row spacing and plant arrangement. McFerran et al (1963) indicated that decreasing the within-row spacing of 'Clemson Spineless' okra reduced the amount of branching, which concentrated the fruit on the central flower stalk. Hermann et al. (1990) grew 'Clemson Spineless' okra in a greenhouse and observed that number of leaves, leaf area, number of generative nodes, and dry matter per plant were reduced as plant population density increased. Olasantan (2001) also found reduced branching and reduced leaf area as plant population density increased in okra. Hermann et al. (1990) further stated that

Received for publication 21 Nov. 2002. Accepted for publication 11 Apr. 2003. Approved for publication by the Director, Oklahoma Agricultural Experiment Station. This research was supported in part under project $\mathrm{H}-2026$. The information given in this publication is for educational purposes only. Mention of a trademark, proprietary product, or vendor does not constitute a guarantee or warranty of the product, nor does it imply approval or disapproval to the exclusion of other products or vendors that may also be suitable.

${ }^{1}$ Former Graduate Research Assistant.

${ }^{2}$ Professor; to whom reprint requests should be addressed. E-mail: bakahn@okstate.edu

${ }^{3}$ Professor.

${ }^{4}$ Professor Emeritus. mine the responses of okra plant architecture to HD plant arrangements, and to consider the implications of those responses for destructive mechanical harvest.

\section{Materials and Methods}

Six experiments were conducted during a 5-year period at the Vegetable Research Station in Bixby, Okla., on a Severn very fine sandy loam [coarse-silty, mixed (calcareous), thermic Typic Udifluvent] with an average organic C concentration of $4 \mathrm{~g} \cdot \mathrm{kg}^{-1}$ at a depth of 0 to 15 $\mathrm{cm}$. Each experiment occupied a different field at the station, and followed a rotational crop of soybean [Glycine $\max (\mathrm{L}$.) Merr.] grown and harvested in the previous year. Weeds were controlled with preplant-incorporated trifluralin [2,6-dinitro- $N, N$-dipropyl-4-(trifluoromethyl) benzenamine] at $560 \mathrm{~g} \cdot \mathrm{ha}^{-1}$ and by hoeing. Insects were controlled with malathion [O,O-dimethyl $S$-(1,2-dicarboxyethyl) phosphorodithioate] at $1.4 \mathrm{~kg} \cdot \mathrm{ha}^{-1}$ as needed. No foliar disease control products were applied. Overhead sprinkler irrigation was provided to supplement rainfall, based on subjective observations of plants and soils.

'Clemson Spineless 80' okra was used exclusively, except in 1995 when four other cultivars were included. Seeds were sown with a vacuum-metering, ultranarrow-row precision planter developed by two of the authors (Solie and Whitney), except in 1996 when a handpushed seeder was used. Raw (non-enhanced) seed was used in all years except 1994, when seed that had been solid matrix primed was used. Priming was for $3 \mathrm{~d}$, after which seeds were allowed to dry back (for details, see Conway et al., 2001).

Architectural data were obtained from four to six plants per plot in each experiment. Plants in HD plots were destructively harvested by hand (simulating a mechanical harvest) for yield responses. Plants were sampled for architectural data at the time of the first destructive harvest for yield, which occurred when overmature fruits first were evident. Plant architecture samples were taken from control and HD plots on the same date. Since plants in control plots were repeatedly and nondestructively hand harvested for yield, control plant samples for architectural data were taken outside the areas chosen to undergo repeated hand harvests. Therefore, fruits had not yet been removed from eitherHD plants or control plants that were sampled for architectural data. Plants were cut with lopping shears and brought to the laboratory for measurement. Architectural data taken on each sampled plant included overall height, height to the point of attachment for the first bloom or fruit and the first marketable fruit, and number of branches (not counting the main stem). Fruits were graded into immature (pods $<5 \mathrm{~cm}$ long), marketable, and overmature (pods $\geq 5 \mathrm{~cm}$ long with palpable fiber development) categories, then counted. In Expts. 1, 2, 3 , and 6 , after architectural data were obtained, defruited plants were dried for $\geq 7 \mathrm{~d}$ at $50{ }^{\circ} \mathrm{C}$ and weighed. Further experimental details are provided elsewhere (Wu et al., 2003).

Expt. 1, 1992. The soil was prepared with a 
broadcast preplant-incorporated application of $51 \mathrm{~N}-22 \mathrm{P}-42 \mathrm{~K}\left(\mathrm{~kg} \cdot \mathrm{ha}^{-1}\right)$, plus trifluralin. Seeds were sown on 18 June 1992 in standard beds that were $2.1 \mathrm{~m}$ wide and not raised. The conventional spacing (control) was $90 \mathrm{~cm}$ between rows and $23 \mathrm{~cm}$ between plants within rows, with two rows per bed. Three HD arrangements were $15 \times 15 \mathrm{~cm}$ (10 rows per bed), $23 \times 23$ $\mathrm{cm}$ (seven rows per bed), and $30 \times 30 \mathrm{~cm}$ (five rows per bed). A split-block design with three replications was used. Main plots (8 $\mathrm{m}$ long) were spacings, arranged in randomized blocks, while subplots ( $4 \mathrm{~m}$ long) were harvest dates. The control did not have subplots; data areas for yield in control rows were $2.5 \mathrm{~m}$ long. Plants in HD plots were destructively harvested by hand for yield on 11 and 18 Sept. Sampling for plant architecture occurred on 11 Sept.

Expt. 2, 1993. The soil was prepared with a broadcast preplant-incorporated application of $73 \mathrm{~kg} \cdot \mathrm{ha}^{-1}$ of $\mathrm{N}$, plus trifluralin. Adequate $\mathrm{P}$ and $\mathrm{K}$ were available from fertilization of previous trials. Seeds were sown on 17 June 1993 using the same spacings as in Expt. 1. A split-block design with three replications was used, and plot sizes were identical to those in Expt. 1. Plants in HD plots were destructively harvested by hand for yield on 3 and 23 Sept. Sampling for plant architecture occurred on 3 Sept.

Expt. 3, 1994. The soil was prepared with a broadcast preplant-incorporated application of $36 \mathrm{~N}-16 \mathrm{P}-30 \mathrm{~K}\left(\mathrm{~kg} \cdot \mathrm{ha}^{-1}\right)$, plus trifluralin. Seeds were sown on 10 May 1994 using the same spacings as in Expt. 1. Plot sizes and overall layout in the field were similar to Expt. 1, but there were four replications and no subplots; instead, $4 \mathrm{~m}$ of each HD plot were used for an initial destructive hand harvest for yield on 7 July (randomized complete-block design). Cut plants then regrew from their stumps to allow two subsequent destructive hand harvests for yield. Sampling for plant architecture occurred only on 7 July.

Expt.4, 1994. Soil preparation was identical to that for Expt. 3. Seeds were sown on 24 May 1994 using the same spacings as in Expt. 1. A split-block design with four replications was used, and plot sizes were identical to those in Expt. 1. Plants in HD plots were destructively harvested by hand for yield on 26 Aug. and 6 Sept. Sampling for plant architecture occurred on 26 Aug.

Expt. 5, 1995. The soil was prepared with a broadcast preplant-incorporated application of $87 \mathrm{~N}-38 \mathrm{P}-72 \mathrm{~K}\left(\mathrm{~kg} \cdot \mathrm{ha}^{-1}\right)$, plus trifluralin. Seeds of 'Annie Oakley II', 'Clemson Spineless 80', 'Emerald', 'Green Best', and 'Lee' were sown on 15 June 1995 . Beds were $2.1 \mathrm{~m}$ wide and not raised. All cultivars were spaced at $25 \mathrm{~cm}$ between rows and $20 \mathrm{~cm}$ within rows, with six rows per bed. This study was designed to be a HD cultivar trial, so there were no conventionally spaced controls. Plots were $8 \mathrm{~m}$ long and arranged in randomized complete blocks, with four replications.

The intent was to use mechanical harvest in this study, but difficulties with the machine caused a delay. Therefore, plants in 4 $\mathrm{m}$ of each plot were destructively harvested by hand for yield on 11 Aug. Sampling for plant architecture occurred on 11 Aug. Plants in the remaining $4 \mathrm{~m}$ of each plot were then harvested on 18 Aug. using an experimental machine developed by Oklahoma State Univ. A sickle bar on the machine cut the plants at an average of $\approx 25 \mathrm{~cm}$ above ground level. A gathering reel deposited the cut plants onto a conveyer belt that transported them to a collection bin. The entire apparatus was mounted on a frame adapted from a self-propelled sprayer. Bins were unloaded at the end of each plot. Stalks were defruited by hand and pods were collected in bags for later grading and data recording. Fruits left behind in the field by the machine also were collected by hand and graded in order to estimate the efficiency of the mechanical harvester.

The entire study was topdressed with urea to supply $45 \mathrm{~kg} \cdot \mathrm{ha}^{-1}$ of N on $23 \mathrm{Aug}$. Amechanical harvest for yield occurred on 10 Oct. for the regrown plants in the $4 \mathrm{~m}$ of each plot previously harvested by hand. Plants in the areas mechanically harvested on 18 Aug. did not regrow enough to permit a second harvest.

Expt. 6, 1996. The soil was prepared with a broadcast preplant-incorporated application of $35 \mathrm{~kg} \cdot \mathrm{ha}^{-1}$ of $\mathrm{N}$, plus trifluralin. Adequate $\mathrm{P}$ and $\mathrm{K}$ were available from fertilization of previous trials. Seeds were sown on 17 May 1996 at an average rate of six seeds per $30 \mathrm{~cm}$ in standard beds that were $2.1 \mathrm{~m}$ wide and not raised. Seedlings were thinned on 10 June to achieve desired within-row spacings. The conventional spacing (control) was $90 \mathrm{~cm}$ between rows and $23 \mathrm{~cm}$ between plants within rows, with two rows per bed. Three HD arrangements were $25 \times 25 \mathrm{~cm}$ (six rows per bed), $38 \times 38$ $\mathrm{cm}$ (five rows per bed), and $50 \times 50 \mathrm{~cm}$ (four rows per bed). These spacings were chosen to encourage branching following an initial destructive harvest. Plots were $6 \mathrm{~m}$ long and arranged in randomized complete blocks, with four replications.

Plants in the full $6 \mathrm{~m}$ of each HD plot were destructively harvested by hand for yield on 15 July. The entire experiment was topdressed with urea to supply $45 \mathrm{~kg} \cdot \mathrm{ha}^{-1}$ of $\mathrm{N}$ on $19 \mathrm{July}$. Cut plants regrew from their stumps, and a destructive hand harvest of the regrowth for yield occurred on 26 Aug. Sampling for plant architecture occurred only for the 15 July harvest.

Statistical analysis. Each experiment was analyzed separately. Data were evaluated by analysis of variance procedures. A square root transformation was applied to raw data before analysis when counts (fruit and branch number per plant) were involved; however, the transformation proved unnecessary in all cases except Expt. 4. Duncan's multiple range test was used for mean separation.

\section{Results}

Expt. 1. Plant population density had no effect on plant height or fruit number per plant (Table 1). The position of the first bloom or fruit attachment and of the first marketable fruit attachment became higher on the stem in plants grown at the $15 \times 15 \mathrm{~cm}$ spacing compared with control plants, while branch number per plant decreased to near zero. There were no significant differences in response between plants spaced at $15 \times 15 \mathrm{~cm}$ vs. those spaced at $23 \times 23 \mathrm{~cm}$. Individual plants in the two most densely spaced treatments weighed much less than those at wider spacings (Table 1).

Expt. 2. The only measured plant architecture variables that showed a response to plant population density were branch number and dry weight per plant, both of which decreased steadily as plant population density increased (Table 2).

Expt. 3. Plant population density had no effect on plant height or marketable fruit number per plant (Table 3). The position of the first bloom or fruit attachment and of the first marketable fruit attachment became higher on the stem in plants grown at the $23 \times$ 23 spacing compared with control plants, and became even higher in plants spaced at $15 \times$ $15 \mathrm{~cm}$. Total fruit number per plant and branch number per plant decreased as plant population density increased. Individual plants in the two most densely spaced treatments weighed less than those at wider spacings (Table 3).

Expt. 4. Plant population density had no effect on plant height (Table 4). The position of the first bloom or fruit attachment and of the first marketable fruit attachment became higher on the stem in densely spaced plants compared with control plants, while fruit and branch number per plant decreased. Effects were evident even when comparing plants spaced at $30 \times 30 \mathrm{~cm}$ to control plants. There were no significant differences in response between plants spaced at $23 \times 23 \mathrm{~cm}$ vs. those spaced at $30 \times 30 \mathrm{~cm}$, and only one difference

Table 1. Okra plant architecture data from 11 Sept. 1992 harvest, Expt. 1. ${ }^{\mathrm{z}}$

\begin{tabular}{|c|c|c|c|c|c|c|c|c|}
\hline \multirow{3}{*}{$\begin{array}{l}\text { Spacing } \\
(\mathrm{cm})\end{array}$} & \multirow{3}{*}{$\begin{array}{l}\text { Plants per } \\
\text { ha } \times 10^{3}\end{array}$} & \multicolumn{3}{|c|}{$\mathrm{Ht}(\mathrm{cm})$ from soil to: } & & & \multirow{3}{*}{$\begin{array}{l}\text { Branches } \\
\text { per } \\
\text { plant (no.) }\end{array}$} & \multirow{3}{*}{$\begin{array}{c}\text { Defruited } \\
\text { dry wt } \\
\text { (g/plant) }\end{array}$} \\
\hline & & \multirow{2}{*}{$\begin{array}{l}\text { Highest } \\
\text { plant part }\end{array}$} & \multirow{2}{*}{$\begin{array}{c}\text { First bloom } \\
\text { or fruit } \\
\text { attachment }\end{array}$} & \multirow{2}{*}{$\begin{array}{c}\text { First } \\
\text { marketable } \\
\text { fruit } \\
\text { attachment }\end{array}$} & \multicolumn{2}{|c|}{$\begin{array}{l}\text { Fruit per plant } \\
\text { (no.) }\end{array}$} & & \\
\hline & & & & & Marketable & Total & & \\
\hline $15 \times 15$ & $175.0 \mathrm{a}$ & 158 & $136 \mathrm{a}$ & $136 \mathrm{a}$ & 0.7 & 2.0 & $0.1 \mathrm{c}$ & $39 \mathrm{c}$ \\
\hline $23 \times 23$ & $88.5 \mathrm{~b}$ & 160 & $127 \mathrm{ab}$ & $135 \mathrm{a}$ & 1.1 & 3.2 & $0.8 \mathrm{c}$ & $70 \mathrm{c}$ \\
\hline $30 \times 30$ & $43.2 \mathrm{c}$ & 158 & $115 \mathrm{~b}$ & $115 \mathrm{~b}$ & 1.3 & 4.0 & $5.2 \mathrm{~b}$ & $171 \mathrm{~b}$ \\
\hline $90 \times 23$ & $40.0 \mathrm{c}$ & 153 & $116 \mathrm{~b}$ & $116 \mathrm{~b}$ & 1.0 & 3.6 & $8.4 \mathrm{a}$ & $248 \mathrm{a}$ \\
\hline \multicolumn{9}{|c|}{ Main effect of spacing } \\
\hline Spacing & $* *$ & NS & $*$ & ** & NS & NS & $* *$ & $* *$ \\
\hline
\end{tabular}


Table 2. Okra plant architecture data from 3 Sept. 1993 harvest, Expt. $2 .^{\mathrm{z}}$

\begin{tabular}{|c|c|c|c|c|c|c|c|}
\hline \multirow{3}{*}{$\begin{array}{l}\text { Spacing } \\
(\mathrm{cm})\end{array}$} & \multirow{3}{*}{$\begin{array}{c}\text { Plants per } \\
\text { ha } \times 10^{3}\end{array}$} & \multicolumn{2}{|c|}{ Ht $(\mathrm{cm})$ from soil to: } & \multirow{2}{*}{\multicolumn{2}{|c|}{$\begin{array}{l}\text { Fruit per plant } \\
\text { (no.) }\end{array}$}} & \multirow{3}{*}{$\begin{array}{l}\text { Branches } \\
\text { per } \\
\text { plant (no.) }\end{array}$} & \multirow{3}{*}{$\begin{array}{c}\text { Defruited } \\
\text { dry wt } \\
\text { (g/plant) }\end{array}$} \\
\hline & & \multirow{2}{*}{$\begin{array}{l}\text { Highest } \\
\text { plant part }\end{array}$} & \multirow{2}{*}{$\begin{array}{c}\text { First bloom } \\
\text { or fruit } \\
\text { attachment }\end{array}$} & & & & \\
\hline & & & & Marketable & Total & & \\
\hline $15 \times 15$ & $174.6 \mathrm{a}$ & 93 & 86 & 0.2 & 0.3 & $0.2 \mathrm{~d}$ & $28 \mathrm{c}$ \\
\hline $23 \times 23$ & $96.4 \mathrm{~b}$ & 90 & 71 & 0.1 & 0.8 & $2.2 \mathrm{c}$ & $38 \mathrm{bc}$ \\
\hline $30 \times 30$ & $54.0 \mathrm{c}$ & 78 & 60 & 0.1 & 0.8 & $3.9 \mathrm{~b}$ & $71 \mathrm{~b}$ \\
\hline $90 \times 23$ & $37.0 \mathrm{~d}$ & 73 & 53 & 0.3 & 1.1 & $8.3 \mathrm{a}$ & $132 \mathrm{a}$ \\
\hline & & & Main ef & of spacing & & & \\
\hline Spacing & $* *$ & NS & NS & NS & NS & $* *$ & $* *$ \\
\hline
\end{tabular}

${ }^{2}$ The $90 \times 23 \mathrm{~cm}$ spacing is the control. If main effect of spacing is significant, mean separation in columns is by Duncan's multiple range test, $P \leq 0.05$. Analysis was not possible on height from soil to first marketable fruit attachment due to the low number of plants with marketable fruit.

ns, *** Nonsignificant or significant at $P \leq 0.01$, respectively.

Table 3. Okra plant architecture data from 7 July 1994 harvest, Expt. 3. ${ }^{2}$

\begin{tabular}{|c|c|c|c|c|c|c|c|c|}
\hline \multirow{3}{*}{$\begin{array}{l}\text { Spacing } \\
(\mathrm{cm})\end{array}$} & \multirow{3}{*}{$\begin{array}{c}\text { Plants per } \\
\text { ha } \times 10^{3}\end{array}$} & \multicolumn{3}{|c|}{$\mathrm{Ht}(\mathrm{cm})$ from soil to: } & & & \multirow{3}{*}{$\begin{array}{l}\text { Branches } \\
\text { per } \\
\text { plant (no.) }\end{array}$} & \multirow{3}{*}{$\begin{array}{l}\text { Defruited } \\
\text { dry wt } \\
\text { (g/plant) }\end{array}$} \\
\hline & & \multirow{2}{*}{$\begin{array}{l}\text { Highest } \\
\text { plant part }\end{array}$} & \multirow{2}{*}{$\begin{array}{c}\text { First bloom } \\
\text { or fruit } \\
\text { attachment }\end{array}$} & \multirow{2}{*}{$\begin{array}{c}\text { First } \\
\text { marketable } \\
\text { fruit } \\
\text { attachment }\end{array}$} & \multicolumn{2}{|c|}{$\begin{array}{l}\text { Fruit per plant } \\
\text { (no.) }\end{array}$} & & \\
\hline & & & & & Marketable & Total & & \\
\hline $15 \times 15$ & $125.3 \mathrm{a}$ & 53 & $35 \mathrm{a}$ & $40 \mathrm{a}$ & 1.0 & $2.4 \mathrm{c}$ & $0.0 \mathrm{c}$ & $17 \mathrm{c}$ \\
\hline $23 \times 23$ & $88.1 \mathrm{~b}$ & 52 & $26 \mathrm{~b}$ & $35 \mathrm{~b}$ & 1.3 & $3.6 \mathrm{~b}$ & $0.6 \mathrm{bc}$ & $24 \mathrm{c}$ \\
\hline $30 \times 30$ & $48.5 \mathrm{c}$ & 55 & $25 \mathrm{bc}$ & $34 \mathrm{~b}$ & 1.3 & $4.3 \mathrm{a}$ & $1.4 \mathrm{~b}$ & $38 \mathrm{~b}$ \\
\hline $90 \times 23$ & $29.4 \mathrm{~d}$ & 49 & $22 \mathrm{c}$ & $29 \mathrm{c}$ & 1.4 & $4.6 \mathrm{a}$ & $3.6 \mathrm{a}$ & $85 \mathrm{a}$ \\
\hline \multicolumn{9}{|c|}{ Main effect of spacing } \\
\hline Spacing & $* *$ & NS & $* *$ & $* *$ & NS & ** & $* *$ & $* *$ \\
\hline
\end{tabular}

${ }^{2}$ The $90 \times 23 \mathrm{~cm}$ spacing is the control. If main effect of spacing is significant, mean separation in columns is by Duncan's multiple range test, $P \leq 0.05$.

ns, ** Nonsignificant or significant at $P \leq 0.01$, respectively.

Table 4. Okra plant architecture data from 26 Aug. 1994 harvest, Expt. 4. ${ }^{2}$

\begin{tabular}{|c|c|c|c|c|c|c|c|}
\hline \multirow{3}{*}{$\begin{array}{l}\text { Spacing } \\
(\mathrm{cm})\end{array}$} & \multirow{3}{*}{$\begin{array}{c}\text { Plants per } \\
\text { ha } \times 10^{3}\end{array}$} & \multicolumn{3}{|c|}{ Ht $(\mathrm{cm})$ from soil to: } & & & \multirow{3}{*}{$\begin{array}{c}\text { Branches } \\
\text { per } \\
\text { plant (no.) }\end{array}$} \\
\hline & & \multirow{2}{*}{$\begin{array}{l}\text { Highest } \\
\text { plant part }\end{array}$} & \multirow{2}{*}{$\begin{array}{l}\text { First bloom } \\
\text { or fruit } \\
\text { attachment }\end{array}$} & \multirow{2}{*}{$\begin{array}{c}\text { First } \\
\text { marketable } \\
\text { fruit } \\
\text { attachment }\end{array}$} & \multicolumn{2}{|c|}{$\begin{array}{l}\text { Fruit per plant } \\
(\text { no. })^{\mathrm{y}}\end{array}$} & \\
\hline & & & & & Marketable & Total & \\
\hline $15 \times 15$ & $212.2 \mathrm{a}$ & 148 & $138 \mathrm{a}$ & $150 \mathrm{a}$ & {$[0.4] 0.3 \mathrm{c}$} & {$[1.0] 0.8 \mathrm{c}$} & {$[0.0] 0.0 \mathrm{c}$} \\
\hline $23 \times 23$ & $106.0 \mathrm{~b}$ & 151 & $127 \mathrm{ab}$ & $132 \mathrm{ab}$ & [1.1] $0.9 \mathrm{bc}$ & {$[2.8] 2.6 \mathrm{~b}$} & {$[0.2] 0.2 \mathrm{bc}$} \\
\hline $30 \times 30$ & $57.4 \mathrm{c}$ & 148 & $117 \mathrm{~b}$ & $127 \mathrm{~b}$ & [1.2] $1.0 \mathrm{~b}$ & [4.2] $3.5 \mathrm{~b}$ & [1.6] $1.1 \mathrm{~b}$ \\
\hline $90 \times 23$ & $36.7 \mathrm{~d}$ & 138 & $98 \mathrm{c}$ & $103 \mathrm{c}$ & [4.2] $3.8 \mathrm{a}$ & [10.2] $9.5 \mathrm{a}$ & [9.8] $9.3 \mathrm{a}$ \\
\hline \multicolumn{8}{|c|}{ Main effect of spacing } \\
\hline Spacing & $* *$ & NS & $* *$ & $* *$ & $* *$ & $* *$ & $* *$ \\
\hline
\end{tabular}

${ }^{2}$ The $90 \times 23 \mathrm{~cm}$ spacing is the control. If main effect of spacing is significant, mean separation in columns is by Duncan's multiple range test, $P \leq 0.05$.

y Variability was such that when a square root transformation was applied to the raw data, results differed from those obtained from an analysis of the non-transformed data. Raw data means are shown in brackets, followed by back-transformed means with their mean separation letters.

ns, ** Nonsignificant or significant at $P \leq 0.01$, respectively. in response between plants spaced at $15 \times 15$ $\mathrm{cm}$ vs. those spaced at $23 \times 23 \mathrm{~cm}$. However, there were pronounced differences between plants spaced at $15 \times 15 \mathrm{~cm}$ and those spaced at $30 \times 30 \mathrm{~cm}$ (Table 4).

Expt. 5. 'Emerald' and 'Lee' did not produce adequate stands and were dropped from the study. The remaining three cultivars did not differ in stand and averaged $101.9 \times 10^{3}$ plants/ha. These three cultivars did not differ in plant height or in numbers of marketable fruit and branches per plant on 11 Aug. (Table 5). The position of the first bloom or fruit attachment and of the first marketable fruit attachment was higher on 'Clemson Spineless 80' than on 'Annie Oakley II' or 'Green Best'. 'Clemson Spineless 80 ' also had the fewest total fruits per plant on 11 Aug. By 1 week later (18 Aug.), both total and marketable yields per hectare were lowest for 'Clemson Spineless 80' (Table 6). 'Green Best' had some fruits $\leq 20 \mathrm{~cm}$ off the ground (Table 5) that were not marketable (overmature) on 18 Aug. and were missed by the harvester (Table 6). The three cultivars did not differ in mechanical harvest efficiency for marketable fruit on $18 \mathrm{Aug}$. or on $10 \mathrm{Oct}$. (Table 6). Regrowth potential (in terms of stems available for a regrowth harvest after initial cutting) was similar among the three cultivars (Table 5). However, the total fruit yield per hectare was much greater for 'Annie Oakley II' and 'Green Best' than for 'Clemson Spineless 80' on 10 Oct. (Table 6). Marketable fruit weights on 10 Oct. were so low that no significant differences were detectable (Table 6).

Expt. 6. The $50 \times 50 \mathrm{~cm}$ spacing resulted in $38.1 \times 10^{3}$ plants/ha, which was less than the control population of $44.4 \times 10^{3}$ plants/ha (Table 7). Plants spaced at $50 \times 50 \mathrm{~cm}$ were shorter and had a lower first marketable fruit attachment than control plants, but did not differ from the control in branch number or dry weight per plant. Plant population density did not affect fruit number per plant. Plants spaced at $25 \times 25 \mathrm{~cm}$ had very little branching and had the lowest dry weights (Table 7).

\section{Discussion}

Growing okra in plant arrangements more densely planted than the control (which was

Table 5. Okra plant architecture data, Expt. 5. ${ }^{2}$

\begin{tabular}{|c|c|c|c|c|c|c|c|}
\hline \multirow[b]{3}{*}{ Cultivar } & \multicolumn{3}{|c|}{$\mathrm{Ht}(\mathrm{cm})$ from soil to: } & & & \multirow{3}{*}{$\begin{array}{l}\text { Branches } \\
\text { per } \\
\text { plant (no.) }\end{array}$} & \multirow{3}{*}{$\begin{array}{c}\text { Cut stems } \\
\text { remaining } \\
\text { per regrown } \\
\text { plant (no.) }\end{array}$} \\
\hline & \multirow{2}{*}{$\begin{array}{l}\text { Highest } \\
\text { plant part }\end{array}$} & \multirow{2}{*}{$\begin{array}{l}\text { First bloom } \\
\text { or fruit } \\
\text { attachment }\end{array}$} & \multirow{2}{*}{$\begin{array}{c}\text { First } \\
\text { marketable } \\
\text { fruit) } \\
\text { attachment }\end{array}$} & \multicolumn{2}{|c|}{$\begin{array}{l}\text { Fruit per plant } \\
\text { (no.) }\end{array}$} & & \\
\hline & & & & Marketable & Total & & \\
\hline Annie Oakley II & 60 & $30 \mathrm{~b}$ & $35 \mathrm{~b}$ & 1.9 & $3.8 \mathrm{a}$ & 1.5 & 3.1 \\
\hline Clemson Spineless 80 & 72 & $43 \mathrm{a}$ & $47 \mathrm{a}$ & 1.4 & $2.1 \mathrm{~b}$ & 0.6 & 2.8 \\
\hline Green Best & 54 & $19 \mathrm{~b}$ & $36 \mathrm{~b}$ & 1.4 & $4.6 \mathrm{a}$ & 1.1 & 2.9 \\
\hline \multicolumn{8}{|c|}{ Main effect of cultivar } \\
\hline Cultivar & NS & $* *$ & $*$ & NS & $* *$ & NS & NS \\
\hline
\end{tabular}


Table 6. Okra fruit yields from destructive mechanical harvests, Expt. 5. ${ }^{2}$

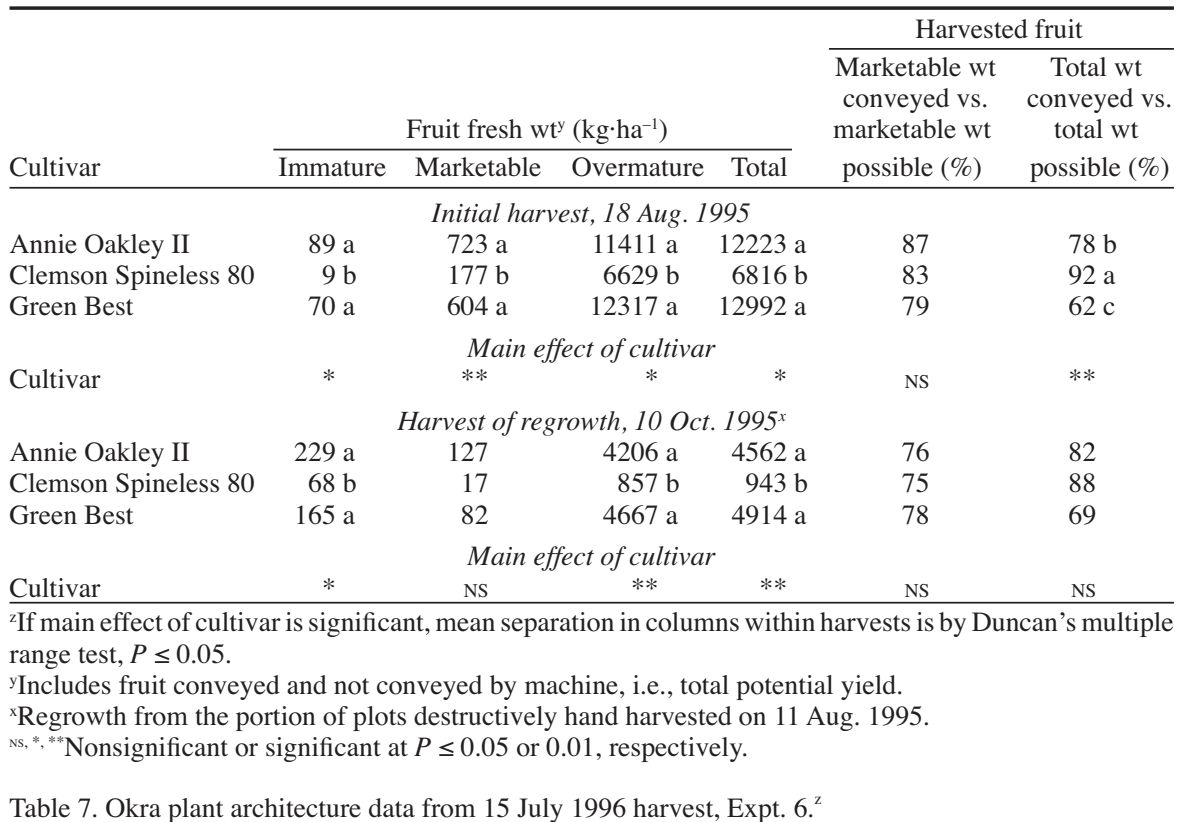

\begin{tabular}{|c|c|c|c|c|c|c|c|c|}
\hline \multirow{3}{*}{$\begin{array}{l}\text { Spacing } \\
(\mathrm{cm})\end{array}$} & \multirow{3}{*}{$\begin{array}{c}\text { Plants per } \\
\text { ha } \times 10^{3}\end{array}$} & \multicolumn{3}{|c|}{$\mathrm{Ht}(\mathrm{cm})$ from soil to: } & & & \multirow{3}{*}{$\begin{array}{l}\text { Branches } \\
\text { per } \\
\text { plant (no.) }\end{array}$} & \multirow{3}{*}{$\begin{array}{l}\text { Defruited } \\
\text { dry wt } \\
\text { (g/plant) }\end{array}$} \\
\hline & & \multirow{2}{*}{$\begin{array}{l}\text { Highest } \\
\text { plant part }\end{array}$} & \multirow{2}{*}{$\begin{array}{l}\text { First bloom } \\
\text { or fruit } \\
\text { attachment }\end{array}$} & \multirow{2}{*}{$\begin{array}{c}\text { First } \\
\text { marketable } \\
\text { fruit } \\
\text { attachment }\end{array}$} & \multicolumn{2}{|c|}{$\begin{array}{l}\text { Fruit per plant } \\
\text { (no.) }\end{array}$} & & \\
\hline & & & & & Marketable & Total & & \\
\hline $25 \times 25$ & $114.3 \mathrm{a}$ & $40 \mathrm{a}$ & 16 & $20 \mathrm{a}$ & 0.8 & 2.3 & $0.5 \mathrm{c}$ & $17 \mathrm{c}$ \\
\hline $38 \times 38$ & $63.5 \mathrm{~b}$ & $37 \mathrm{a}$ & 15 & $19 \mathrm{ab}$ & 1.1 & 3.2 & $1.9 \mathrm{~b}$ & $33 \mathrm{~b}$ \\
\hline $50 \times 50$ & $38.1 \mathrm{~d}$ & $33 \mathrm{~b}$ & 14 & $15 \mathrm{~b}$ & 0.9 & 2.7 & $2.8 \mathrm{a}$ & $48 \mathrm{a}$ \\
\hline $90 \times 23$ & $44.4 \mathrm{c}$ & $38 \mathrm{a}$ & 17 & $21 \mathrm{a}$ & 0.8 & 3.0 & $2.3 \mathrm{ab}$ & $53 \mathrm{a}$ \\
\hline \multicolumn{9}{|c|}{ Main effect of spacing } \\
\hline Spacing & $* *$ & $*$ & NS & $*$ & NS & NS & ** & $* *$ \\
\hline
\end{tabular}

${ }^{2}$ The $90 \times 23 \mathrm{~cm}$ spacing is the control. If main effect of spacing is significant, mean separation in columns is by Duncan's multiple range test, $P \leq 0.05$.

${ }_{\text {Ns, }}^{*, * *}$ Nonsignificant or significant at $P \leq 0.05$ or 0.01 , respectively.

spaced at $90 \times 23 \mathrm{~cm})$ did not affect overall plant heights (from the soil to the highest plant part). Plant height was affected only in Expt. 6, where plants in the $50 \times 50 \mathrm{~cm}$ arrangement were shorter than control plants (Table 7). Okra plant height has responded inconsistently to plant population, as previously noted. Kerby et al. (1990) also found that plant population density did not affect plant height in two relatively short cotton cultivars. Time of sampling relative to plant ontogeny may help explain the inconsistent height responses of Malvaceae crops such as okra and cotton to increased plant populations (Buxton et al., 1977; Hermann et al., 1990).

The position of the first bloom or fruit attachment and of the first marketable fruit attachment tended to become higher on the stem as plant population density increased, especially when comparing plants from the $15 \times$ $15 \mathrm{~cm}$ spacing to control plants. A similar trend was found for okra by Hermann et al. (1990) as plant population densities increased from four to 16 plants per $\mathrm{m}^{2}$, and also for cotton by Buxton et al. (1977). 'Clemson Spineless 80' also had a higher first fruit attachment than the other two tested cultivars (Table 5). Kerby et al. (1990) reported that cotton cultivars differed in nodal position of the first fruiting branch. Having the lowest fruit relatively high above the soil may be an advantage for mechanical harvesting (Buxton et al., 1977; Marshall, 1984). In the mechanical harvests of Expt. 5, efficiency of fruit recovery by the machine was highest for 'Clemson Spineless 80' on 18 Aug., but there were no differences in efficiency of marketable fruit recovery among the three tested cultivars (Table 6). Many more non-marketable (primarily overmature) fruit were left behind by the harvester on plants of 'Annie Oakley II' and 'Green Best' compared with plants of 'Clemson Spineless 80' during the 18 Aug. harvest (Table 6).

The total number of fruit per plant sometimes decreased as plant population density increased, but the number of marketable fruit per plant was affected by plant population only in Expt. 4 (Table 4). Fatokun and Chheda (1983), Olasantan (2001), and Whitehead and Singh (2000) also observed a decrease in the number of okra fruit per plant as plant population density increased. Richardson (1972) pointed out that the number of marketable okra fruit per plant at any harvest was relatively constant.

Branch number per plant decreased as plant population density increased in all of our experiments. Differences were dramatic, as it was not uncommon for control plants to have eight or nine branches at sampling time vs. less than one branch per plant from the
$15 \times 15 \mathrm{~cm}$ spacing (for example, see Tables 1,2 , and 4). This finding supports previous studies (Fatokun and Chheda, 1983; McFerran et al., 1963; Patterson and Morelock, 1979; Whitehead and Singh, 2000). Accompanying the reduction in branching was a reduction in defruited dry weight per plant when comparing control plants to plants from HD treatments (Tables 1, 2, 3, 7). Asimilar dry weight response was found in other experiments on densely planted okra(Kahn etal., 2003). Large branches can hinder mechanical harvesting (Buxton et al., 1977; Marshall, 1984), so reduced branching with HD spacings would be an advantage. Reduced overall plant mass with HD spacings also would mean less trash in the harvested product with a destructive harvest.

The okra plant architecture responses to HD spacings documented in these experiments were mostly favorable for a destructive mechanical harvest system. The relatively low marketable fruit yields obtained with the mechanical harvests in Expt. 5 reflected unfavorable timing, as evidenced by the high weight of overmature fruit, rather than difficulties with the machine gathering available fruit. Most of the studies were with 'Clemson Spineless 80', an open-pollinated cultivar with relatively inexpensive seed (thus amenable to planting at a high rate). Seed cost would be a greater limiting factor than plant architecture to the potential use of hybrids such as 'Annie Oakley II' in a HD planting for destructive harvest. The lack of a concentrated marketable fruit set (Düzyaman, 1997) appears to be the main limiting factor to the success of densely planted okra for destructive harvest.

\section{Literature Cited}

Abdul, K.S. and L.H. Aarf. 1986. Effects of plant spacing and fertilizer levels on the growth and yield of okra. Iraqi J. Agr. Sci. (ZANCO) 4(2): 77-89.

Buxton, D.R., R.E. Briggs, L.L. Patterson, and S.D. Watkins. 1977. Canopy characteristics of narrow-row cotton as influenced by plant density. Agron. J. 69:929-933.

Conway, K.E., R. Mereddy, B.A. Kahn, Y. Wu, S.W. Hallgren, and L. Wu. 2001. Beneficial effects of solid matrix chemo-priming in okra. Plant Dis. 85:535-537.

Düzyaman, E. 1997. Okra: Botany and horticulture,p. 41-72. In: J. Janick (ed.). Horticultural reviews, vol. 21. Wiley, New York.

Fatokun, C.A. and H.R. Chheda. 1983. The influence of population density on yield and yield components of okra [Abelmoschus esculentus (L.) Moench]. Acta Hort. 123:273-281.

Gupta,A., K. Srinivas, and V. Shukla. 1981. Response of okra (Abelmoschus esculentus L.) to plant spacing and nitrogen, phosphorus fertilization. Indian J. Hort. 38:218-222.

Hermann, M., M. Makadji, and H.J. Daunicht. 1990. Effect on intra-row spacing on time course of growth and fruit yield of okra. Scientia Hort. 45:37-48.

Kahn, B.A., J.R. Cooksey, and J.E. Motes. 1997. Within-row spacing effects on traits of importance to mechanical harvest in paprika-type peppers. Scientia Hort. 69:31-39.

Kahn, B.A., Y. Wu, N.O. Maness, J.B. Solie, and R.W. Whitney. 2003. Densely planted okra for destructive harvest: III. Effects of nitrogen nutri- 
tion. HortScience 38:1370-1372.

Kerby, T.A., K.G. Cassman, and M. Keeley. 1990.

Genotypes and plant densities for narrow-row cotton systems. I. Height, nodes, earliness, and location of yield. Crop Sci. 30:644-649.

Marshall, D.E. 1984. Horticultural requirements for mechanical pepper harvesting, p. 389-396. In: Amer. Soc. Agr. Eng. (ASAE) Proc. Intl. Symp. on Fruit, Nut, and Veg. Harvesting Mechanization, Bet Dagan, Israel, 5-12 Oct. 1983. ASAE Publ. 5-84.

McFerran, J., G.A. Bradley, and H.L. Bowden.
1963. Production of Clemson Spineless okra. Ark. Farm Res. 12(2): 10

Olasantan,F.O. 2001. Optimum plant populations for okra (Abelmoschus esculentus) in a mixture with cassava (Manihotesculenta) and its relevance to rainy season-based cropping systems in southwestern Nigeria. J. Agr. Sci. 136:207-214.

Patterson, W.K. and T.E. Morelock. 1979. Effects of variety and spacing on okra yield. Ark. Farm Res. 28(6):8.

Richardson, M.K. 1972. Mechanical harvesting of okra. Trans. Amer. Soc. Agr. Eng. 15:
1021-1023.

Whitehead, W.F. and B.P. Singh. 2000. Yield, time of maximum $\mathrm{CO}_{2}$ exchange rate, and leaf-area index of 'Clemson Spineless' okra are affected by within-row spacing. HortScience 35:849-852.

Wu, Y., B.A. Kahn, N.O. Maness, J.B. Solie, R.W. Whitney, and K.E. Conway. 2003. Densely planted okra for destructive harvest: I. Effects on yield. HortScience 38:1360-1364.

Zahara, M. 1970. Influence of plant density of yield on process tomatoes for mechanical harvest. J. Amer. Soc. Hort. Sci. 95:510-512. 